\title{
Induction of lactation: an economic study of tool for dairy heifers with successive reproductive failures
}

\author{
Andressa Stein Maffi ${ }^{1}$ (D) Gabriela Bueno Luz ${ }^{1}$ (D) Bernardo Garziera Gasperin ${ }^{2}$ (D) \\ Raine Fonseca Mattos ${ }^{3}$ Eduardo Gularte Xavier $^{4}$ Marcio Nunes Corrêa $^{4}$ Cássio Cassal Brauner ${ }^{3^{*}}$ (iD)
}

${ }^{1}$ Programa de Pós-graduação em Zootecnia, Departamento de Zootecnia, Núcleo de Pesquisa, Ensino e Extensão em Pecuária (NUPEEC), Faculdade de Agronomia Eliseu Maciel, Universidade Federal de Pelotas (UFPel), Pelotas, RS, Brasil.

${ }^{2}$ Departamento de Patologia, Faculdade de Veterinária, Universidade Federal de Pelotas (UFPel), Pelotas, RS, Brasil

${ }^{3}$ Departamento de Zootecnia, Núcleo de Pesquisa, Ensino e Extensão em Pecuária (NUPEEC), Universidade Federal de Pelotas (UFPel), 96010-900, Pelotas, RS, Brasil. E-mail: cassiocb@gmail.com. *Corresponding author.

${ }^{4}$ Programa de Pós-graduação em Veterinária, Núcleo de Pesquisa, Ensino e Extensão em Pecuária (NUPEEC), Faculdade de Veterinária, Universidade Federal de Pelotas (UFPel), Pelotas, RS, Brasil.

ABSTRACT: The aim of this study was to evaluate the economic viability of the use of a lactation induction protocol in Holstein heifers. Were collected data of nutritional, reproductive and sanitary management pre and post-lactation period from 30 induction heifers (IG) and 30 pregnant heifers $(C G)$. All animals were inseminated around 14 months of age and started lactation at $23 \pm 4$ months. The animals of IG were heifers do not pregnant after two inseminations and natural service e were induced to lactation according to protocol: from the $1^{\text {st }}$ to the $8^{\text {th }}$ day, $30 \mathrm{mg}$ of estradiol benzoate were administered daily, together with $300 \mathrm{mg}$ of progesterone. From the $9^{\text {th }}$ until the $14^{\text {th }}$, animals only received daily doses of $20 \mathrm{mg}$ estradiol benzoate. On $16^{\text {th }}$ day, $0.56 \mathrm{mg}$ of sodium cloprostenol was administered and injections of $40 \mathrm{mg}$ of dexamethasone sodium phosphate were administered daily from the $19^{\text {th }}$ to the $21^{\text {st }}$ day. On the $1^{\text {st, }} 8^{\text {th }}$, $15^{\text {th }}$ and $22^{\text {nd }}$ day, the animals received a dose of sometribove zinc. The animals of CG were managed according to the farm routine. The costs of the CG during pre and post lactation (nutrition, sanitary, reproduction management) e were higher than the IG, however, when evaluating the economic viability due to lower milk production, the induced group did not leave profit in the first year of use. When comparing the lactation induction with the sale of animals that did not conceive and purchase of animals for replacement, this last scenario showed itself as a better alternative.

Key words: economic viability, heifers, induced lactation.

Indução de lactação: levantamento econômico da utilização desta ferramenta em novilhas leiteiras com sucessivas falhas reprodutivas

RESUMO: O objetivo deste estudo foi avaliar a viabilidade econômica do uso de um protocolo de indução a lactação em novilhas da raça Holandês. Foram coletados dados econômicos do manejo nutricional, reprodutivo e sanitário pré e pós lactação de 30 novilhas induzidas à lactação (IG) e 30 novilhas prenhes (CG). Todos os animais foram inseminados em torno de 14 meses de idade e iniciaram a lactação com aproximadamente $23 \pm 4$ meses. Os animais do IG foram novilhas que não conceberam após duas inseminações e monta natural, e foram induzidas à lactação com o protocolo: do $1^{\circ}$ ao $8^{\circ}$ dia receberam aplicação de $30 \mathrm{mg}$ de benzoato de estradiol juntamente com $300 \mathrm{mg}$ de progesterona. A partir do $9^{\circ}$ dia até o $14^{\circ}$ receberam $20 \mathrm{mg}$ de benzoato de estradiol. No dia 16 ocorreu uma aplicação de $0.56 \mathrm{mg}$ cloprostenol sódico e nos dias 19 ao 21, de $40 \mathrm{mg}$ de dexametasona. Nos dias 1, 8, 15, e 22, os animais receberam 500 mg somatotropina recombinante bovina. Os animais do CG foram manejados conforme a rotina da propriedade. Os custos do CG durante o pré e lactação (nutrição, sanidade, reprodução) foram superiores ao grupo induzido. No entanto, ao avaliar a viabilidade econômica, devido a menor produção leiteira, o grupo induzido não deixou lucro na propriedade no primeiro ano de utilização. Ao comparar a indução de lactação com a venda de animais que não conceberam e a compra de animais para reposição, este último cenário mostrou-se como uma melhor alternativa.

Palavras -chave: viabilidade econômica, novilhas, indução de lactação.

\section{INTRODUCTION}

Milk production can be as competitive as any other endeavor in terms of return on invested capital, but for this to be true, it is necessary to achieve high efficiency in the production system. Reproductive efficiency failures are among the main factors that affect profitability in the milk production chain (BUTLER, 2000). In recent years, animal selection for genetic qualities aimed at increasing milk yield has resulted in a reduction in the reproduction of dairy cows (LUCY, 2001, WALSH et al., 2011, PRITCHARD et al., 2013). 
Reproductive problems also occur in heifers, due to nutrition, health management, or endocrine changes. According to LE COLZER (2010), heifers undergo puberty when they reach $40 \%$ to $50 \%$ of adult weight, which normally occurs near 10 months of age and $318 \mathrm{~kg}$ of weight on average for the Holstein breed. However, a percentage above of $50 \%$ of animals, despite being of adequate age and weight, do not become pregnant after first AI (GONZALES et al., 2015, LUZ et al., 2018), and successive reproductive interventions and are culled without beginning productive life in the farm. The early culling of these animals is detrimental to the system, as heifers are responsible for herd renovation and genetic improvement. Besides that, the current cost of producing dairy heifers in the pre- and post-weaning phases is estimated at 1611.75 USD (SANTOS \& BELONI, 2016), representing 15-20\% of the total cost that goes into the production system (SANTOS et al., 2001).

A possible alternative that has been utilized to increase the productive life of the animals when they are not pregnant or calving, and to avoid the early culling of heifers, is the use of protocols for inducing lactation. These protocols aims to simulate exogenously the hormonal endocrine profile of cows in the peripartum period, inducing the lactogenesis process, which begins milk synthesis (MELLADO et al., 2011). In previous studies, researchers observed a success rate of approximately $85-100 \%$ for inducing heifers, who then went on to produce from $65 \%$ to over $78 \%$ as much as animals in physiological lactation (MELLADO et al., 2006; FREITAS et al., 2010). Beyond the productive benefits, reports observed that after induction females which have previously failed to conception, presented an improvement in reproductive performance, reaching pregnancy rates of approximately $40-75 \%$ (SMITH \& SCHANBACHER, 1973; FREITAS et al., 2010; MELLADO et al., 2011). PESTANO et al. (2015) and other authors proposed that this effect is due to the long exposure to estrogen during the lactation induction protocol, when compared to the estrous cycle, which acts on the uterine environment and on ovarian function, causing changes in the endocrine profile of the animals (FREITAS et al., 2010).

Even though lactation induction is a tool that was developed a long time ago, there are still only few studies in Brazil regarding the productive, reproductive, and economic outcome. The objective of this study was to evaluate the economic viability of the lactation induction technique in dairy heifers in comparison to pregnant heifers, as well as the sale of non-productive animals and purchase of animals for replacement.

\section{MATERIALS AND METHODS}

The data used in this study was collected from retrospective data of dairy farm located in Brazil. For the economic survey, we collected data from 30 induction heifers (Induction Group, IG) and 30 pregnant heifers (Control Group, CG). The CG animals began lactation in the same period as the IG animals, after completing $23 \pm 4$ months (Figure 1). The data collected included the period from the first artificial insemination (AI) after puberty of the animals until the end of the first lactation (305 days) and included data on nutritional, sanitary, reproductive, and productive management of the animals (Figure 1).

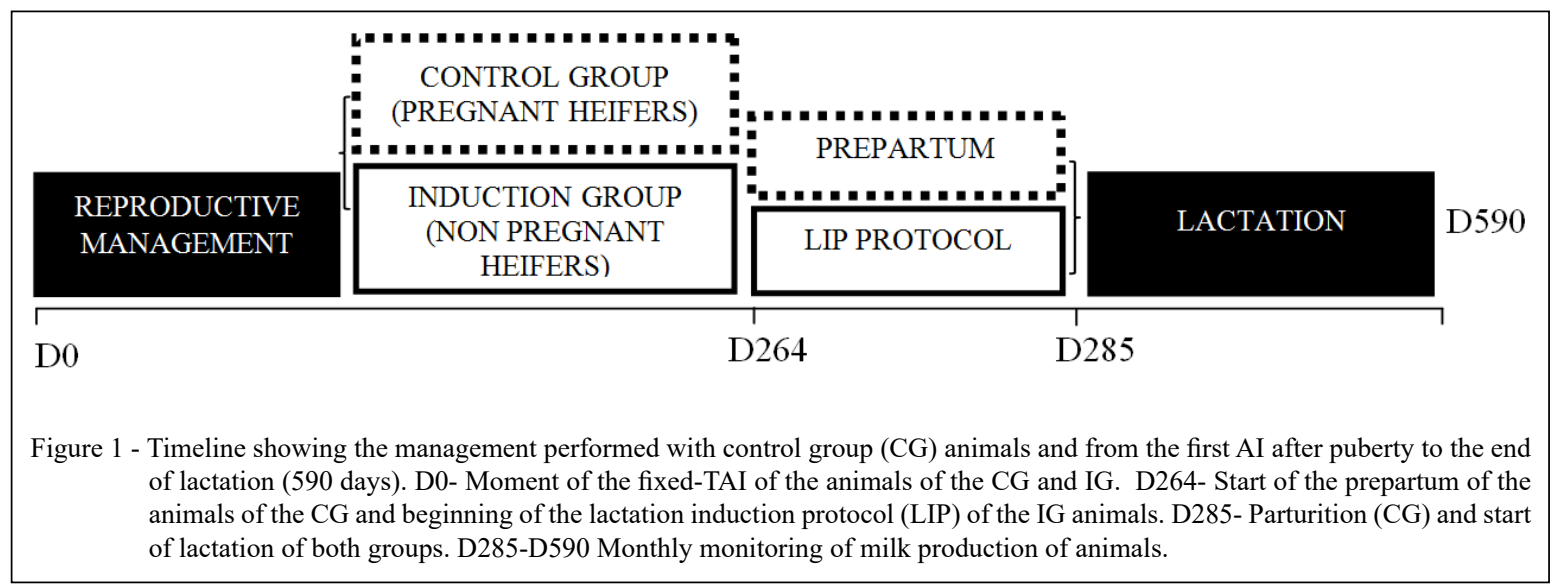

Ciência Rural, v.49, n.12, 2019. 
Reproductive management and lactation induction protocol (LIP)

All the heifers, around 14 months of age, were submitted at the same time to a protocol of timed artificial insemination (TAI): each heifer was assigned to receive $2 \mathrm{mg}$ of estradiol benzoate (Gonadiol $^{\circledR}$ Zoetis, São Paulo, Brazil) and the insertion of an intravaginal device containing $1.9 \mathrm{~g}$ of progesterone (CIDR ${ }^{\circledR}$ Zoetis, São Paulo, Brazil) on day 0 of the protocol. At day 7, $12.5 \mathrm{mg}$ of dinoprost (Lutalyse ${ }^{\circledR}$ Zoetis, São Paulo, Brazil) was injected. At day 9 , the intravaginal device was removed, and 12.5 mg of dinoprost (Lutalyse ${ }^{\circledR}$ Zoetis, São Paulo, Brazil) and $0.6 \mathrm{mg}$ of estradiol cypionate (E.C.P. ${ }^{\circledR}$ Zoetis, São Paulo, Brazil) were administered to the animals. At day 11, TAI was performed. Pregnancy diagnoses were performed by ultrasound approximately 30 days post-AI. Animals that were not pregnant were submitted to a second AI, following the same procedures described above.

After these procedures, we selected 60 animals, which were divided into two groups: the CG ( $n=30$, pregnant heifers) and the IG $(n=30$, non-pregnant heifers). The heifers in the IG were submitted to the artificial Lactation Induction Protocol (LIP), at the time that the cows of the control group were completing 8 months of gestation, according to the following methods: from days 1 to $8,30 \mathrm{mg}$ of estradiol benzoate (Sincrodiol ${ }^{\circledR}$ Ourofino Saúde Animal, São Paulo, Brazil) was injected daily, together with $300 \mathrm{mg}$ of progesterone (Sincrogest ${ }^{\mathbb{B}}$ Ourofino Saúde Animal, São Paulo, Brazil), via I.M. From days 9 to 14, animals received a daily dose of $20 \mathrm{mg}$ of estradiol benzoate (Sincrodiol ${ }^{\circledR}$ Ourofino Saúde Animal, São Paulo, Brazil). On day 16, 0.56 mg of sodic cloprostenol (Sincrocio ${ }^{\circledR}$ Ourofino Saúde Animal, São Paulo, Brazil) was administered, and from days 19 to 21, $40 \mathrm{mg}$ of dexamethasone sodium phosphate (Cortiflan ${ }^{\circledR}$ Ourofino Saúde Animal, São Paulo, Brazil) was administered. In addition, on days $1,8,15$, and $22,500 \mathrm{mg}$ of sometribove zinc (Lactotropin $^{\circledR}$ Elanco Saúde Animal, São Paulo, Brasil) was administered.

\section{Sanitary management}

The sanitary management practices utilized were in accordance with the farm's routine practices. The CG heifers, during the pregnancy, received vaccination for bovine infectious rhinotracheitis (IBR), bovine viral diarrhea (BVD), leptospirosis, keratoconjunctivitis, and carbuncle, and received an application of vermifuge. The IG heifers, during the induction of lactation protocol, were vaccinated for same diseases. From the beginning of lactation, all animals received the same management.

\section{Nutritional management}

The CG heifers, in the first month were managed in native field, from the second to eighth months of pregnancy were managed at grasslandcultivated pasture (Lolium multiflorum) with an animal load of $480 \mathrm{~kg} / \mathrm{ha}$. At 21 days prepartum, they began to receive a diet based on corn silage with $43 \%$ neutral detergent fiber (NDF), 25\% acid detergent fiber (ADF), and $15 \%$ crude protein $(\mathrm{CP})$, twice a day. The IG during the nine months were managed in native field, and received same supplementation of CG was during the 21 days of the induction protocol.

At the beginning of lactation, which occurred on the same day of partum for cows of the control group and on the 21 day after the initiation of the induction protocol for cows of the induction group, the 60 females were handled in a Compost Barn system. With milking twice a day, a diet of corn silage and concentrate with 35\% NDF, $20 \% \mathrm{ADF}$, and $16 \% \mathrm{CP}$, completely mixed according to NRC (2001), and water ad libitum.

\section{Methodology for calculating costs}

For calculations referring to sanitary management, we considered the vaccinations carried out at the farm during the follow-up period. The cost of each vaccine dose, as well as the number of applications over time, was taken into account. In relation to the costs of nutritional management of the $\mathrm{CG}$, we considered the cost of depreciation of the natural field at a rate of $3 \mathrm{~kg}$ of $\mathrm{ox} / \mathrm{month} / \mathrm{ha}$, according to the methodology used in the region where the study was realized, plus the cost of pasture preparation (soil preparation, fertilization, and seed price), and, finally, the cost of the concentrated diet offered in the pre- and post-partum. For the IG, the costs were the same, with the exception of the cost of pasture, because the animals were managed in a native field prior to the initiation of the lactation induction protocol, and during the 21 days of the protocol, in addition to the native field, they received the same prepartum diet of the cows of the control group. For reproductive management, we considered the costs of each hormone dose, and the conception rate. In the control group, the cost of the protocol was calculated based on the conception rate of the group that was $50 \%$. The methodology for the IG costs included those associated with the two TAI protocols (limits stipulated by the farm), as well as the costs associated with the applications of the 
hormones for the induction protocol (estradiol, progesterone, dexamethasone, prostaglandin, bst). All values for the products used in the management protocols were obtained from agricultural and livestock website, except for the costs associated with the concentrated diet that was provided to both groups during the 21 days before lactation and during the postpartum period, and the application of sometribove zinc (bST).

The calculation of economic viability considered the sum of the costs of each group in the pre- and post-lactation period and the subtraction of the profit from the sale of milk (pre-lactation cost + post-lactation cost - milk sales profit). To calculate the profit from the sale of milk, we considered the average production of each group during the study period versus the amount paid to the producer in the month, according to the Center for Advanced Studies in Applied Economics (CEPEA) website. In these calculations, we do not include costs associated with labor or equipment maintenance.

\section{RESULTS AND DISCUSSION}

The costs associated with the nutritional, sanitary, and reproductive management protocols used during the pre- and post-lactation periods are presented in tables 1 and 2 . A viability calculation that takes into account the average milk production during the 305 days of lactation is also presented in the tables. The costs within each group are presented per animal, and as the total for all animals in each group.

In table 1, we included the costs related to reproductive, sanitary, and nutritional management, calculated for the period before parturition (CG) or before lactation (IG). In terms of reproductive management, both groups entailed similar costs. However, it should be pointed out that the money invested was 915.90 USD (30.53 USD/animal) higher in the CG than in the IG, mainly due to the costs associated with nutritional management of the pregnant heifers. The diet of pregnant animals demands increased daily requirements of energy, calcium, phosphorus, and crude protein for maintenance and development of the fetus (NRC, 2001). Meanwhile the IG heifers, that is, nonpregnant females, were kept in the native field without supplementation during 9 months, and only began to create higher expenses in terms of nutrition from the period in which they entered the induction protocol, which lasted only 21 days.

Table 2 describes the costs related to management protocols after milking started. The costs associated with nutritional and sanitary management after the beginning of lactation are similar between groups, even though bST applications increased the costs for the IG, which received applications every seven days during the induction protocol and every 14 days during the lactation period. Meanwhile, for the $\mathrm{CG}$, the applications started only 60 days after the beginning of lactation, with intervals of 14 days,

Table 1 - Costs with reproductive, sanitary and nutritional management before the parturition (CG) and before the lactation (IG)

\begin{tabular}{|c|c|c|c|c|}
\hline \multirow[t]{2}{*}{ Management } & \multicolumn{2}{|c|}{ 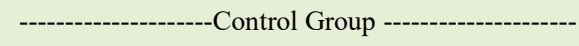 } & \multicolumn{2}{|c|}{ 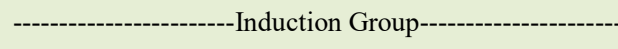 } \\
\hline & $\begin{array}{l}\text { Cost/cow } \\
\text { (USD) }\end{array}$ & $\begin{array}{c}\text { Cost/group (USD) } \\
n=30\end{array}$ & $\begin{array}{l}\text { Cost/cow } \\
\text { (USD) }\end{array}$ & Cost/group (USD) $n=30$ \\
\hline Reproductive & $36.10^{1}$ & 1083,00 & $36.10^{2}$ & 1083,00 \\
\hline $\mathrm{LIP}^{5}$ & - & - & 92.30 & 2769.00 \\
\hline Sanitary & 9.23 & 276.09 & 9.23 & 276.90 \\
\hline Nutritional & $232.20^{3}$ & 6966.00 & $109.37^{4}$ & 3281.25 \\
\hline Overall & 277.53 & 8325.90 & 247.00 & 7410.00 \\
\hline $\begin{array}{l}{ }^{*} \text { USD } 3.20=\mathrm{R} \\
{ }^{*} \text { Depreciation } \\
{ }^{*} \text { Prepartum die } \\
{ }^{1} \text { Corrected co } \\
\text { (conception ra } \\
{ }^{2} \text { Cost to perfor } \\
{ }^{3} \text { Cost related t } \\
{ }^{4} \text { Costs related } \\
{ }^{5} \text { Lactation Ind }\end{array}$ & $\begin{array}{l}\mathrm{Kg} \text { of ox/ } \mathrm{h} \\
\text { day. } \\
\text { unt the nun } \\
\text { otocols with } \\
\text { the native fi } \\
\text { f the native }\end{array}$ & $\begin{array}{l}\text { ox } \mathrm{Kg}=\mathrm{USD} 1.25) \text {. } \\
\text { ixed-TAI necessary } \\
\text { intation of the ryegras } \\
\text { he diet offered in the }\end{array}$ & $\begin{array}{l}\text { f the ney } \\
\text { d the prep } \\
\text { in inductio }\end{array}$ & ies to become pregnant \\
\hline
\end{tabular}

Ciência Rural, v.49, n.12, 2019. 
Table 2 - Costs with, reproductive, nutritional and sanitary management of pregnant (CG) and induced heifers (IG) postpartum.

\begin{tabular}{|c|c|c|c|c|}
\hline \multirow[t]{2}{*}{ Management } & \multicolumn{2}{|c|}{-------------------------'Control Group----------------------- } & \multicolumn{2}{|c|}{ 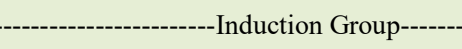 } \\
\hline & Cost/animal (USD) & $\begin{array}{c}\text { Cost/group } \\
\text { (USD) } \\
n=30\end{array}$ & $\begin{array}{l}\text { Cost/animal } \\
\text { (USD) }\end{array}$ & $\begin{array}{c}\text { Cost/group } \\
\text { (USD) } \\
n=30\end{array}$ \\
\hline Reproductive & ${ }^{1} 45.90$ & 1377.00 & ${ }^{2} 57.37$ & 1721.10 \\
\hline Sanitary & 16.24 & 487.20 & 16.24 & 487.20 \\
\hline Nutritional & 2252.24 & 67567.20 & 2252.24 & 67567.20 \\
\hline bST & 90.00 & 2700.00 & 112.50 & 3375.00 \\
\hline TOTAL & 2404.38 & 72131.40 & 2438.35 & 73150.50 \\
\hline
\end{tabular}

${ }^{*} \mathrm{USD} 3.20=\mathrm{R} \$ 1.00$

*Postpartum diet- USD 7.38 /animal/day

*bST- USD 5.62

${ }^{1}$ Corrected cost taking into account the number of fixed-TAI necessary for $100 \%$ of the new pregnancies to become pregnant (conception rate $=50 \%$ ).

${ }^{2}$ Corrected cost taking into account the number of fixed-TAI necessary for $100 \%$ of the new pregnancies to become pregnant (conception rate $=40 \%$ ).

representing four fewer applications per animal during the 305 days of lactation. In addition, the animals in the induced group had a lower conception rate (GI: $40 \%$ versus CG: $50 \%$ ), raising the costs of the protocol. Thus, we can observe that the IG cost 1019.10 USD (33.97/animal USD) more than CG during the 305 days of milking.

The sum of all the management costs for both groups during the pre- and post-lactation periods are described in table 3 . We found that irrespective of the group, the biggest investment occurs during the post-lactation period, mainly because of the high costs associated with the specialized diet required for the animals to produce milk at maximum capacity. Nutritional requirements of dairy cows with high milk yield increases after calving, thus, the total ration provided during this period must contain 16 to $18 \%$ of crude protein, 17 to $22 \%$ of ADF, and less than $30 \%$ of NDF (NRC, 2001). The NRC (2001) proposes that, in the first three weeks of lactation, the diet should contain $19 \%$ of crude protein and 38 to $40 \%$ of rumen non-degradable protein, with the purpose of compensating for low dry matter intake. We found that the sum of the management costs preand post-lactation for both groups indicates that the costs are similar, however the induced animals have a higher cost of 103.20 USD (3.44 USD/animal) over the 590 days that the animals were monitored.

However, for a real evaluation of the economic return generated by these animals in the farm, it is necessary to consider the total milk production of each group. The data referring to the average production per animal and per group during the 305 days of lactation and the gross profit, referring to the sale of milk, can be found in table 4. The IG produced $77 \%$ of that by $C G$, with an

Table 3 - Summarized description of pre and post-lactation costs.

\begin{tabular}{|c|c|c|c|c|c|c|}
\hline \multirow[b]{2}{*}{ Groups } & \multicolumn{2}{|c|}{----------'Pre-lactation (USD)---'---' } & \multicolumn{2}{|c|}{-----Post-lactation (USD)------- } & \multicolumn{2}{|c|}{ 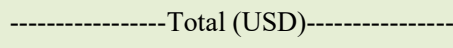 } \\
\hline & Cost/cow & $\begin{array}{l}\text { Cost group } \\
\quad(n=30)\end{array}$ & Cost/cow & $\begin{array}{l}\text { Cost group } \\
\quad(n=30)\end{array}$ & Cost/cow & $\begin{array}{l}\text { Cost group } \\
\quad(n=30)\end{array}$ \\
\hline $\begin{array}{l}\text { Control } \\
\text { Group }\end{array}$ & 277.53 & 8325.90 & 2404.38 & 72131.40 & 2681.91 & 80457.30 \\
\hline $\begin{array}{l}\text { Induction } \\
\text { Group }\end{array}$ & 247.00 & 7410.00 & 2438.35 & 73150.50 & 2685.35 & 80560.50 \\
\hline
\end{tabular}

${ }^{*} \mathrm{USD} 3.20=\mathrm{R} \$ 1.00$.

Ciência Rural, v.49, n.12, 2019. 
Table 4 - The profit from the sale of milk.

\begin{tabular}{lcccc}
\hline Groups & Milk yield/animal (305 DIM) & Milk yield/group (305 DIM) & $\begin{array}{c}\text { Revenue/animal } \\
\text { (Milk sales) (USD) }\end{array}$ & $\begin{array}{c}\text { Revenue/group } \\
(\text { Milk sales) (USD) }\end{array}$ \\
\hline Control Group & $8777.43^{1}$ & 263322.9 & 3347.64 & 100429.30 \\
Induction Group & $6775.04^{2}$ & 203251.2 & 2574.83 & 77245.06 \\
\hline
\end{tabular}

${ }^{*} \mathrm{USD} 3.20=\mathrm{R} \$ 1.00$.

${ }^{1}$ Control Group Milk Yield: 28.76 liters/day; (minimum 21.36 liters/day; maximum 32.35 liters/day).

${ }^{2}$ Induction Group Milk Yield: 22.21 liters/day (minimum 8.41 liters/day; maximum 26.37 liters/day).

${ }^{3}$ Price paid per liter of milk based on the Centro de Estudos Avançados em Economia Aplicada (CEPEA): R\$ 1.22 (minimum: 1.18 ; maximum: 1.33 ) $=$ US\$0.38 (minimum: 0.36; maximum: 0.41 ).

average daily production of $22.21 \mathrm{~L}(\mathrm{IG})$ and 28.76 $\mathrm{L}(\mathrm{CG})$, respectively.

The costs associated with management pre- and post-lactation and the gross profit referring to the sale of milk (Table 5), show the economic viability calculations of the induction of lactation, in comparison to the physiological gestation. As can be observed, CG animals yield a profit of USD 19972.00 (665.73/animal), while IG animals incur a loss of USD -3315.44 (-110. 32/ animal). The line between obtaining profit, or not, in the first year of lactation induction is closely related to the productive capacity of the animals destined to this procedure and also to the price paid per liter of milk to the producer.

Taking into account that an alternative to performing lactation induction in animals not responsive to reproductive management would be the sale of "problem" animals and purchase of animals for replacement, we compared this scenario in table 6 .

When we compare scenarios two and three, representing the possible alternatives for the animals that did not become pregnant, the sale of heifers and purchase of female non-pregnant replacements represents a better alternative than the induction protocol. We must take into consideration that the sale of the animal will result in an early culling and the need for a high-value investment to purchase a new heifer (MAGLIARO et al., 2004; RAMGATTIE et al., 2014). Instead, with the use of induction, this animal will remain in the farm and may become pregnant in the next reproductive cycle, as several studies report the return to reproductive activity after the induction protocol (SMITH \& SCHANBACHER, 1973; FREITAS et al., 2010; MELLADO et al., 2011). This would allow the heifer to be inseminated, become pregnant, and produce physiological lactation. However, it is important to note that induced cows had a conception rate of $40 \%$ at first AI, when compared to the animals with physiological gestation that had a conception rate of $50 \%$. In a similar study, RAMGATTIE et al. (2014) considered four different scenarios when evaluating the viability of the lactation induction protocol: in scenario one, a cow, instead of being culled, was induced to lactate; in scenario two, a heifer was induced to lactate; in scenario three, a cow was sold and another pregnant cow was purchased to replace it; and, in scenario four, a cow was sold and another non-pregnant one purchased for replacement. Different from our study, the author concluded that lactation induction was the

Table 5 - Calculation of viability of the induction protocol taking into account the costs for maintenance of the animals, the protocol and the profit from the sale of milk.

\begin{tabular}{lccccc}
\hline Groups & $\begin{array}{c}\text { Revenue/animal } \\
\text { (Milk sales) (USD) }\end{array}$ & $\begin{array}{c}\text { Revenue/group } \\
\text { (Milk sales) (USD) }\end{array}$ & Cost/animal & $\begin{array}{c}\text { Cost/Group } \\
\text { Total revenue/ } \\
\text { animal }\end{array}$ & $\begin{array}{c}\text { Total revenue/ } \\
\text { group }\end{array}$ \\
\hline $\begin{array}{l}\text { Control Group } \\
\begin{array}{l}\text { Induction } \\
\text { Group }\end{array}\end{array}$ & 3347.64 & 100429.30 & 2681.91 & 80457.30 & 665.73 \\
\hline
\end{tabular}

Ciência Rural, v.49, n.12, 2019. 
Table 6 - Revenue simulation according to 3 scenarios: pregnant heifers, induced heifers, and empty heifers sold to culling after reproductive management that did not result in conception and purchase of female non-pregnant replacements.

\begin{tabular}{|c|c|c|c|c|c|c|}
\hline Scenario & $\begin{array}{c}\text { Pre-lactation } \\
\text { Costs }(n=30) \\
\text { USD }\end{array}$ & $\begin{array}{c}\text { Post-lactation } \\
\text { Costs }(n=30) \\
\text { USD }\end{array}$ & $\begin{array}{c}\text { Revenue } \\
\text { (Milk sales) } \\
\text { USD }^{2}\end{array}$ & $\begin{array}{l}\text { Sale of animals } \\
\text { USD }^{3}\end{array}$ & $\begin{array}{l}\text { Purchase } \\
\text { of female }^{4}\end{array}$ & $\begin{array}{c}\text { Total } \\
\text { Revenue } \\
\text { USD }\end{array}$ \\
\hline $\begin{array}{l}\text { Situation 1: Control } \\
\text { Group }\end{array}$ & 8325.90 & 72131.40 & 100429.30 & - & & 19972.00 \\
\hline $\begin{array}{l}\text { Situation 2: Induction } \\
\text { Group }\end{array}$ & 7410.00 & 73150.50 & 77245.06 & - & & -3315.44 \\
\hline \multicolumn{7}{|l|}{ Situation 3: } \\
\hline $\begin{array}{l}\text { Sale and purchase of } \\
\text { heifers }\end{array}$ & $1439.71^{1}$ & - & - & $15000.00^{4}$ & 18000.00 & -3000.00 \\
\hline
\end{tabular}

${ }^{*} \mathrm{USD} 3.20=\mathrm{R} \$ 1.00$.

${ }^{1}$ Cost referring to the accomplishment of two protocols of fixed-TAI with $0 \%$ of pregnancy, maintenance in native field during 2 months and sanitary protocol.

${ }^{2}$ Price paid per liter of milk based on the Centro de Estudos Avançados em Economia Aplicada (CEPEA): R\$ 1.22 (minimum: 1.18 ; maximum: 1.33 ) $=$ US $\$ 0.38$ (minimum: 0.36 ; maximum: 0.41 .

${ }^{3}$ Price of heifers sale with $400 \mathrm{~kg}$ - USD $1.25 / \mathrm{Kg}$.

${ }^{4}$ Price paid for the purchase of heifers- USD 600.00 .

better alternative when compared with the sale or replacement of the animals.

MACRINA et al. (2011), evaluated induced lactation in pubertal heifers and characterized milk production, growth, reproduction, and herd life. In their study, for the system profitability, the induced lactation of 15-mo-old heifers, as a routine management tool, was not more profitable than traditional management practices. However, differently than our study, MACRINA et al (2011) evaluated induced cows since 15-months old throughout the entire their lifetime and did not consider whether they were reproductive efficient or not.

In addition to using the induction protocol as an alternative for animals with reproductive problems, this technique can also be used to accelerate the productiveness of the animals in the system. Early induction of all the heifers would promote an earlier start of lactation, even before the first parturition. However, the care of the size, weight, and nutritional condition of the animals during milk production is essential to avoid harming them, and not cause future reproductive problems.

\section{CONCLUSION}

The lactation induction protocol in heifers is directly related to the farm costs, particularly with nutritional management, the milking capacity of the cows, and the price of milk paid to the producer.
Besides that, the replacement heifers purchase cost is a key factor to determine the utilization of lactation induction protocol in heifers with consecutives failures reproductive.

\section{ACKNOWLEDGEMENTS}

We thank the Núcleo de Pesquisa, Ensino e Extensão em Pecuária (NUPEEC) and Granjas 4 Irmãos S.A. for providing the animals and farm facilities. Also, special appreciation is extended to the Conselho Nacional de Desenvolvimento Científico e Tecnológico $(\mathrm{CNPq})$ for financial support $\mathrm{MCTIC} / \mathrm{CNPq} \mathrm{N}^{\circ}$ 28/2018), as well as, to Coordenação de aperfeiçoamento de Pessoal de Nível Superior (CAPES), Brasil.

\section{BIOETHICS AND COMMITTEE APPROVAL}

The study was approved by the Ethics Committee on Animal Experimentation of the Universidade Federal de Pelotas (CEEA - UFPel), under protocol number 8716/2016-89.

\section{DECLARATION OF CONFLICT OF INTERESTS}

The authors declare no conflict of interest. The founding sponsors had no role in the design of the study; in the collection, analyses, or interpretation of data; in the writing of the manuscript, and in the decision to publish the results.

\section{AUTHORS' CONTRIBUTIONS}

The authors contributed equally to the manuscript. 


\section{REFERENCES}

BUTLER, W. Nutritional interactions with reproductive performance in dairy cattle. Animal Reproduction Science, v.61, p 449-457, 2000. Available from: <https://doi.org/10.1016/S03784320(00)00076-2>. Accessed: Sep. 29, 2017. doi: 10.1016/S03784320(00)00076-2.

FREITAS, P. R. C. et al. Artificial induction of lactation in cattle. Revista Brasileira de Zootecnia, v.39, p.2268-2272, 2010. Available from: <http://dx.doi.org/10.1590/S151635982010001000024>. Accessed: Sep. 28, 2017. doi: 10.1590/ S1516-35982010001000024.

GONZALEZ, F. et al. Milk yield and reproductive performance of dairy heifers and cows supplemented with polyunsaturated fatty acids. Pesquisa agropecuária brasileira, v.50, p.306312, 2015. Available from: <http://dx.doi.org/10.1590/S0100204X2015000400006>. Accessed: Mar. 05, 2019. doi: 10.1590/ S0100-204X2015000400006.

LE COLZER, Y. et al. Performance and longevity of dairy heifers born during winter 1 (W1) and reared according to three growth profiles during winter 2 (W2) in a strategy based on first calving at 36 months of age. Livestock Science, v. 137, p.244-254, 2010. Available from: <https://doi.org/10.1016/j. livsci.2010.11.018>. Accessed: Sep. 28, 2017. doi: 10.1016/j. livsci.2010.11.018.

LUCY, M. C. Reproductive loss in high producing dairy cattle: where will it end? Journal of Dairy Science, v. 84, p.12771293, 2001. Available from: <https://doi.org/10.3168/jds.S00220302(01)70158-0>. Accessed: Nov. 03, 2017. doi: 10.3168/jds. S0022-0302(01)70158-0.

LUZ, G. B. et al. Effects of the bull on conception rate of dairy cows in different seasons and according to AI type. Acta Scientiae Veterinariae, v.46, n.1, 2018. Available from: <https://doi. org/10.22456/1679-9216.82554>. Accessed: Mar. 05, 2019. doi: $10.22456 / 1679-9216.82554$.

MACRINA, A. L. et al. Induced lactation in pubertal heifers: Efficacy, response to bovine somatrotropin, and profitability. Journal of Dairy Science, v.94, p.1355-1364, 2011. Available from: <https://doi.org/10.3168/jds.S00220302(11)00090-7/>. Accessed: Feb. 20, 2019. doi: 10.3168/ jds.S0022-0302(11)00090-7.

MAGLIARO, A. et al. Induced lactation in nonpregnant cows: Profitability and response to bovine somatotropin. Journal of Dairy Science, v.87, p.3290-3297, 2004. Available from: <https://
doi.org/10.3168/jds.S0022-0302(04)73465-7>. Accessed: Sep. 28, 2017. doi: 10.3168/jds.S0022-0302(04)73465-7.

MELLADO, M. et al. Effect of lactation number, year, and season of initiation of lactation on milk yield of cows hormonally induced into lactation and treated with recombinant bovine somatotropin. Journal of Dairy Science, v.94, p.4524-4530, 2011. Available from: <https://doi.org/10.3168/jds.2011-4152>. Accessed: Nov. 22, 2017. doi: 10.3168/jds.2011-4152.

NRC-NATURAL RESEARCH COUNCIL. Nutrient requeriments of dairy cattle. Seven Revised Edition, 2001, 356p.

PESTANO, H. S. et al. Indução artificial de lactação em bovinos: histórico e evolução. Revista Brasileira de Reprodução Animal, v.39, p.315-321, 2015. Available from: <www.cbra.org.br>. Accessed: Nov. 03, 2017.

PRITCHARD, T. et al. Understanding the genetics of survival in dairy cows. Journal of dairy science. v.96, p.3296-3309, 2013. Available from: $<$ https://www.ncbi.nlm.nih.gov/pubmed/23477814>. Accessed: Jan. 06, 2018. doi: 10.3168/jds.2012-6219.

RAMGATTIE, R. Effect of mammary stimulation on dairy cows and heifers exposed to a lactation induction protocol. Journal of Animal Sciences. v.4, p.1-12, 2014. Available from: <https:// www.scirp.org/journal/PaperInformation. aspx?PaperID $=41645>$. Accessed: Jan. 06, 2018. doi: 10.4236/ojas.2014.41001.

SANTOS, G.; BELONI, T. Production cost preweaning and dairy heifers - A case study. Revista iPecege, v.2, p.29-39, 2016. Available from: <https://doi.org/10.22167/r.ipecege.2016.1.29>. Accessed: Jan. 06, 2018. doi: 10.22167/r.ipecege.2016.1.29.

SANTOS, G.T. et al. Alguns aspectos econômicos e de manejo na criação de novilhas leiteiras. Revista Balde Branco, São Paulo, v.37, p.56-60, Mai. 2001. Available from: $<$ http://www.nupel.uem. br/novilhas02-2000.pdf>. Accessed: Nov. 03, 2017.

SMITH, K.L.; SCHANBACHER, F. L. Hormone induced lactation in the bovine. I. Lactational performance following injections of $17 \beta$-estradiol and progesterone1. Journal of Dairy Science, v.56, p.738-743, 1973. Available from: <https://doi.org/10.3168/jds. S0022-0302(73)85243-9>. Accessed: Nov. 03, 2017. doi: 10.3168/ jds.S0022-0302(73)85243-9.

WALSH, S.W, WILLIAMS, E. J, EVANS, A. C. A review of the causes of poor fertility in high milk producing dairy cows. Animal Reproduction Science. v.3-4, p.127-38, 2011. Available from: $<$ https://www.ncbi.nlm.nih.gov/pubmed/21255947>. Accessed: Jan. 06, 2018. doi: 10.1016/j.anireprosci.2010.12.001. 